Full Terms \& Conditions of access and use can be found at http://www.tandfonline.com/action/journalInformation?journalCode=ycah20

Journal of Community Archaeology \& Heritage

ISSN: 2051-8196 (Print) 2051-820X (Online) Journal homepage:

http://www.tandfonline.com/loi/ycah20

To cite this article: Veysel Apaydin \& Brenna Hassett (2018): Should I stay or should I go? Ideals and realities of archaeology in the conflict regions, Journal of Community Archaeology \& Heritage, DOI: $10.1080 / 20518196.2018 .1549821$

To link to this article: https://doi.org/10.1080/20518196.2018.1549821

Published online: 23 Nov 2018.

\title{
Should I stay or should I go? Ideals and realities of archaeology in the conflict regions
}

\section{Veysel Apaydin and Brenna Hassett}

University College London, Institute of Archaeology, London, UK

\begin{abstract}
Through the Ilısu Dam Rescue Archaeology Project, we explore ethical and practical aspects of rescue archaeology in contested territory and areas of conflict, at the mound sites of Başur H.yük and Çattepe in Siirt Province, Turkey. We are excavating the sites ahead of the Ilisu Dam's construction, a controversial project that the state supports but that others contest. One of the most important characteristics of these heritage sites is their significance for local community identity construction. These places have also witnessed conflict between the state and Kurdish separatists. The project is administered under overlapping hierarchies, which may have different, even competing interests. These manifest in conflicts between 'top-down' approaches to rescue archaeology, and an effective public engagement strategy. We discuss how the project can be a positive force, given the impending destruction through dam construction and the location in the middle of an armed conflict; and when it cannot.
\end{abstract}

\section{KEYWORDS}

Archaeology; heritage; conflict; ethics; public engagement

\section{Introduction}

In cultural heritage studies, engaging with the public, doing community archaeology, and running outreach and education projects in local areas to share both knowledge and power with communities is necessary and useful for increasing heritage awareness and protection of the material culture, though other tools should also support these significant components. These supporting tools include critical factors for sustainability, such as capacity building, job opportunities, and social and economic support. These are particularly significant in underdeveloped and conflict-affected regions of the world, and among communities in poverty.

While some archaeologists see themselves as responsible only for archaeology and material culture, we have also ethical responsibilities towards local communities as well as producing data for archaeology and heritage studies (Zimmerman, Karen Vitelli, and Hollowell-Zimmer 2003; Meskell 2010; Mark 2001). The main reason that we argue that we have particular responsibilities for communities is that heritage is a process (Smith 2006) and people actively shape, change, and transform it. Heritage plays a key role in people's present and future (Ricouer 1999; Ireland and Schofield 2015,2). We consider heritage as a tool to shape the present and future of societies, as 
well as producing a sense of collectivity that supports the social and economic life of communities. Heritage can be a significant tool for social justice and cultural rights, as it may reinforce group identity

and a sense of belonging within communities, creating a more diverse array of communities within a society (see Baird 2014; Logan 2014). Alternatively, it can also be divisive and a source of conflict in many parts of the world (for more on contested heritage, see Silverman 2011; Apaydin 2018a).

As 'heritage' can a very broad term, in this particular project the meaning of heritage includes the material culture of the past, as well as domestic architecture, landscape, and aspects of the natural environment in connection with intangible heritage such as food, songs, and the oral culture of present-day communities. In this paper, we discuss this in the particular context of rescue archaeology in areas of conflict, where ethical considerations must include not only the danger to heritage, but also the danger to local communities, archaeologists and heritage practitioners. We argue that our ethical obligations should include supporting communities which are vulnerable (socially, economically,

mentally and culturally) and which suffer from the trauma of destruction and conflict.

We consider two perspectives of rescue archaeology and their implications for local communities:

(1) communities of archaeological practice in which archaeology should engage effectively with local communities and be able to respond to their social, political and economic needs, and (2), the broader implications for the role of archaeologists in the preservation of cultural heritage in the excavation of two archaeological sites near the town of Siirt, in southeastern Turkey. These perspectives reflect our personal experiences working with the local community to integrate archaeological excavation

with public engagement, education and heritage awareness, capacity building, providing social and cultural opportunities, and working as international researchers in a period of rapidly declining security and political stability.

Archaeological excavations have been ongoing for over 15 years in a region affected by dam construction

(see Figure 1 for the map), with many archaeologists and specialists, mainly from Turkey, but also Italy and the UK. Taking part in rescue excavations in these contested and conflict areas have brought to light many ethical issues as part of wider paradigm of archaeology and heritage studies (Meskell and Pels 2005; Shoup 2006; Hafsaas-Tsakos 2011). In this paper, as an archaeologist and a heritage specialist, we examine several ethical questions:

Figure 1. Location of the proposed Ilisu Dam Impact Zone. Source: @Brenna Hassett.

. Are we part of this destruction or are we 'rescuing' the heritage that is significant for locals and humanity as a whole?

.What can archaeologists and heritage specialists offer to local communities in this complex and sensitive matter?

. How do we need to approach this in theory and practice?

Background and context

The excavations at Çattepe and Başur H.yük in Siirt (Figures 2 and 3), southeastern Turkey, began in 2002 and ended in 2015 due to political instability and the reignition of conflict in the region. The government mandated the excavations as part of the construction of the Ilisu Dam on the Tigris River, which affected three major regional cities: Siirt, Batman and Diyarbakir. Different teams undertook

rescue excavations and surveys, involving Turkish, Italian and British institutions. The State Water Institution (DSI, Devlet Su Isleri) directly funded the project, rather than the Turkish Ministry of Culture.

While still subject to Ministry of Culture oversight, these excavations are unique in Turkey in that they

take place with the knowledge that the cultural heritage that the sites represent will be lost to 
flooding in 2018 (Ronayne 2005, 2006). The expected flooding will affect tens of thousands, destroying

the daily lives of locals in this region, as the flood will affect around $300 \mathrm{~km} 2$. The areas affected contain houses, farms, and grazing areas of the local community, depleting not only livelihood but also the heritage landscapes, which build and store community memory and identity. The area has been home to local people for centuries, in which they have developed tangible and intangible heritage ascribing values and meanings that shape their identity and are important for their sense of belonging (Ashworth and Graham 2005; Graham and Howard 2008), as sense of place is significant for particular group and individuals' social construction (Waterton 2005; McDowell 2008, 38). The region has seen intense conflict for the last 35 years between government forces and Kurdish Autonomist Kurdistan Worker's Party (PKK). This conflict forced locals to leave their houses and surrounding landscape in the 1990s, with tens of thousands displaced individuals (Kitchen and Ronayne 2002; Ronayne 2005). Eviction and displacement have been quite common in this region because of these conflicts and dam construction projects dating back to the 1970s. From the 1980s this construction has become part of a larger paradigm of wider neoliberal policies of development

(Apaydin 2016a), and it is these two issues that create the largest and most long-term damage to local life by permanently destroying local culture. Although since the beginning of 2000 local communities had been allowed by the government to return to their villages, and 2010 witnessed the beginnings of a peace process developing over the next two years, conflict has sparked again in many parts of the southeast region. As a result, in 2015 the state evicted tens of thousands of local residents once again. Furthermore, with the completion of Ilisu dam project a further 75,000 people will be displaced, a process that has already begun in some parts of the area. The Ilisu Dam has a long history in terms of its construction, which is still an ongoing process, with no set completion date agreed, though it is expected to be completed within 2018. Both the framework of the dam construction and rescue excavation take a top-down approach; local communities do not have any say in the decision-making process or directly in the field. Rescue and research archaeology in Turkey operates as part of a very centralized system (Baraldi, Shoup, and Zan 2013) and all decisions are taken at the top (national) level and then implemented regionally. It is almost impossible to involve local communities in the decision-making process, and the Ministry of Culture strictly controls excavations themselves through local museums and ministry representatives at the archaeological sites. However, running a long-term archaeological excavation and survey project offered a unique opportunity to go beyond this traditional rescue strategy. The longevity of the project created opportunities for supporting locals economically and socially, for example through creating job opportunities, offering training and skills, youth education and social integration for women in this conservative region. All these aspects are core components of doing public archaeology (Schadla-Hall 1999; Marshall 2002; Moser et al. 2002; Merriman 2004; Shoup 2012; Moshenska 2017).

Having pointed out these significant aspects of public archaeology, in this paper our aim is not to support the kind of large-scale construction that destroys natural, cultural and intangible heritage, and leads to displacement. This paper does not have the scope to discuss the ethics of rescue archaeology

in toto (see however discussion in Shoup 2006; Ronayne 2006, 2008). Rather than working towards a universal statement of whether rescue archaeology is 'ethical' or not when it continues to occur, we instead emphasize how archaeology of this nature can be beneficial for local communities.

It is necessary to consider that we must not limit the role of archaeologists and heritage specialists to documenting, excavating and surveying the archaeology, or creating and using a data source to further an academic career. Archaeologists can also support local communities, particularly in preserving

and widening access to heritage. We present here our experiences and potential suggestions about the ways in which archaeologists and heritage specialists can support vulnerable local communities

situated in areas of conflict. 


\section{Documentation and exhibition of archaeology and heritage}

A crucial part of working in rescue archaeology is developing effective documentation strategies to record knowledge about material culture of the region, which in this case will be flooded and largely destroyed forever (see Kitchen and Ronayne 2002). Since the project started over 12 years ago, hundreds

of specialists in archaeology, human remains, cultural heritage, botany, photography, filmmaking and other heritage specialisms have worked to map, document and excavate the archaeology of the dam region.

Surface surveys, from the Neolithic period to the medieval ages and even the recent past, allowed mapping of hundreds of archaeological sites (Tuna, Greenhalg, and Velibeyoğlu 2004). Due to limited time, resources and funding, archaeology teams have excavated only a handful of those sites. These excavations exposed tens of thousands of artefacts from Neolithic, Bronze Age and Medieval

periods. Excavation also brought up the issue of storing, preserving and exhibiting these artefacts, as the region did not have a museum at the start of the project. It has been quite common in Turkey to transfer most artefacts from these undeveloped regions to western (developed) parts of Turkey for preservation and exhibition. However, this time the Ministry of Culture decided to build a museum in the region in collaboration with archaeologists, museum and heritage specialists. Although this is still top-down, as local community members were excluded from the final decision-making process, it prompted a uniquely locally oriented perspective that formed the foundation

for successful community engagement. This was also a first step in fostering local interest in archaeological excavations, with a majority of locals delighted to have the first archaeology museum in the region built about a 45-minute drive away from the provincial capital of Siirt, in the town of Batman (Figure 4).

The Batman Archaeology Museum opened in 2012 with small photography exhibition 'Hasankeyf 1911', in collaboration with Newcastle (UK) and Ege (TR) Universities. It focused on the photographs

of the famous explorer and archaeologist Gertrude Bell, who took photos of the archaeology of the region almost 100 years ago. The exhibition became a huge attraction, as it enabled local people to see the oldest existing photos of their landscape and see how it has changed over time. An exhibition exploring the Neolithic and Bronze Age period soon followed the Bell's exhibition. One of the most important contributions of the museum to local communities was non-archaeological: establishing the museum park, giving communities a green space for meeting friends and family, chatting, picnicking,

drinking tea, playing with children, and other important social activities. Archaeology was soon incorporated into the popular space, with experimental replicas of Neolithic, Bronze Age and more recent houses and aspects of social life. While local community members enjoyed the museum and museum park, local secondary schools have used materials from the museum as an educational resource. Creating and disseminating educational resources worked towards this, demonstrating a critical aspect of how cultural heritage can be part of a larger social healing process during conflict and post-conflict periods (Meskell and Scheermeyer 2008).

Along with documenting and exhibiting the material culture of the region's past and present, the archaeology project employed another useful tool, filmmaking, to document ongoing excavations, natural life and intangible heritage using an ethnographic approach (Figure 5). However, filmmaking also brings its own issues: how to record the archaeology, heritage, and local life of a $300 \mathrm{~km} 2$ area? How to employ a 'bottom-up' approach to filmmaking? The project hired five professional filmmakers from Ege University for this purpose to work alongside a heritage specialist (Apaydin) with experience in ethnographic methods.

In the first stage of filming, the team decided to record all rescue excavations of the Ilisu Dam affected area, including 20 archaeological digs. The main reason for shooting ongoing excavations was firstly, to preserve them digitally for future generations and local communities, and to present the landscape and heritage present before the dam floods the region. Additionally, this allowed us 
to record the experience and stories of archaeologists during the excavations, which was also important

as we were part of the heritage-making and destruction. In the second stage of filming, the film crew focused on local stories, developed in parallel to local cultural landscape, intangible heritage and natural heritage. This included tales, songs, and poems that are transferred from one generation to another, through the region's acknowledged oral tradition (Rashidirostami 2018). Following these main stages, the film crew also recorded the material culture of the present. The team aimed at the idea that documentation and recording rescue projects should not be limited to excavations and surveys of archaeology, but should also capture significant components of local identity and memory attached to those landscapes. The flooded areas will cover a very large proportion of the landscape and therefore both cultural and natural heritage are under threat. As an example of the type of intangible heritage documented alongside the excavation work, the team members of the archaeology project also researched local food cultures, then documented and published their findings in a special issue (Sağlamtimur 2009).

\section{Public engagement and education}

In the particular case of the dam rescue excavation projects, what we call 'bottom-up' public engagement

was implemented with the considerable efforts of the director and coordinator of the dam rescue excavations, archaeologists and students. One of the main reasons that this became very effective and successful was that most of the team members were very familiar with the region, its people and cultural settings. Although many participants came from the west, for Turkey the project had a uniquely high level of participation from local residents trained in archaeology and heritage

management. This is crucial in two ways for any public engagement projects in archaeology in any part of the world: (1) having knowledge of dynamics of particular cultural settings provides grounds for effective public engagement to increase heritage awareness, and (2) it is critical to build trust and integrate archaeologists and specialists with the local communities whose heritage it is, although archaeologists often still only use them for 'archaeological data collection' in many parts of the world.

Elsewhere, Apaydin (2018b) argued that local heritage should not be considered as a pure data resource for academic career development (also see Koster, Baccar, and Lemelin 2012, 200; Waterton 2015, 59; Apaydin 2016a). Archaeologists, heritage specialists and academics should be in dialogue with locals rather than isolating themselves (Apaydin 2018c); a 'communicative' approach. Communication

between archaeological and heritage practitioners and local communities is an issue in many archaeology projects (Apaydin 2016a). Since the overall management of the Ilisu Dam Rescue Project is centralized and very top down and locals cannot be involved in high-level decision making, here we present how we overcame this major obstacle to public engagement. We argue that public engagement was possible despite the excavation's top-down structure through developing resources for community members, building relationships with the local communities, and running an education programme for local secondary school students.

The dighouse of the Başur and Çattape H.yük is located $10 \mathrm{~km}$ away from Siirt city centre, and contains a large expanse of land in addition to several unused buildings. The project team used these buildings as dormitories, kitchens, and work areas. Since they have been made into an archaeological

'camp' area, the complex has become quite popular among local community members, who are able to come and visit as the dighouse and land were made open to visitors. The city of Siirt is distant from traditional tourist attractions, has witnessed considerable conflict and political tension, and is economically and socially undeveloped compared to other cities of Turkey. Hence, this was a great attraction for locals as an opportunity to meet the around 80-120 archaeologists and students, many of whom were from other parts of the country and even abroad. While this provided an opportunity for interaction with people whose background was very different from local communities, it also created an opportunity for locals to learn more about the archaeology of the 
region and find out why it is significant to have more knowledge about the material culture of the past and present. For instance, some of the locals pointed out 'until recently, we also used stone foundation and mudbrick materials to build our houses'; 'our grandparents also used kelek, earliest and common water transportation boat in Mesopotamia, to cross the Tigris River for trade and transport goods and people' (see Sağlamtimur and Ozan 2017). The impact of interaction with archaeologists and heritage specialists reflected on the numbers of visitors to the sites as well as exhibitions at the Batman Archaeology Museum (pers. comm., H. Saglamtimur).

In public archaeology and heritage studies, one of the focal points is engaging with the public and sharing knowledge and power (Moshenska and Dhanjal 2011; Moshenska 2017; Apaydin 2018b). It is crucial to have a 'communicative approach', and to be in dialogue with local communities at all times during excavations periods rather than only focusing on structured engagement programmes such as school visits or site 'Open Days'. Dialogue creates opportunity for locals to appreciate archaeology and heritage and its importance, and it enables academics and specialists to understand the cultural settings and socio-cultural dynamics in that particular context (see Freire 1993 for how dialogue method works). Considering our experiences on this project with this two-way flow of information, we argue that the priority of public archaeology and heritage studies should not only aim for preservation of the material culture, but also the protection of the people who develop, attach and ascribe meanings to material culture and contribute to the diversity of the society. The excavation camp not only offered knowledge of archaeology and heritage but also led to the creation of an organic farm in the complex, in which many vegetables were grown and that locals came to enjoy. Moreover, the land associated with the dighouse area become one of the greenest area in the city though the planting and growing of over 2500 trees in a 12-year time span. This is quite significant as the region does not have many green spaces and has many drought-affected areas. Creating this green space gave the opportunity for locals to have a picnic at weekends, further cementing the relationship between the excavation and the local communities. Furthermore, the productive use of the land was not limited to the natural park but, through sponsorships, the director was able to build a sport complex which archaeologists, students, as well as locals from many different communities, can use and enjoy. The running track, for instance, was very popular and on occasion used for 'races' involving not only the Turkish and ethnic Kurdish members of the excavation team but also foreign archaeologists, children of local Kurdish villages.

One of the other significant activities that the archaeology team carried out was the informal education

programme, supported through sponsorship by the local governor and regional council. The director, Haluk Saglamtimur, ran the three-day education programme alongside other team members in 2007 (Figure 6). The programme included on-site lectures, site tours, and a workshop where children could make replicas of the objects. Thirty children attended the workshop. The programme's aim was to give detailed knowledge of the archaeology and heritage of the region before it is wiped out forever. The education programme did not have a specific age target as they were randomly selected from primary and secondary schools. One of the significant contributions of the programme was to consider the social, cultural and economic backgrounds of the participants and running the programme accordingly. This significant aspect of informal education is very often neglected

in devising education programmes (Apaydin 2016b). The education board of the city and local NGOs assisted in the selection process of children for the education programme. Although a threeday programme may not have a large impact, it is significant to be able to offer something to local children who were born and grew up in the context of regional conflict and for this reason do not have the opportunity for many such social activities. Two years later in 2014 Batman Archaeology Museum was able to establish the museum park mentioned above with the collaboration of archaeologists and heritage specialists and began to run these education programmes in a more structured fashion at the museum.

Considering the recent past and present situation of the region, which has seen 35 years of conflict 
where communities have suffered from losing family members, houses, land and arrival of Syrian refugees, we consider these social activities have made contribution to a healing process during the conflict and post-conflict periods. This is important given that people who live in conflict and post-conflict regions need more social support (Summerfield 2000). These contributions by the archaeology project were not only limited to social life but also impacted economic life through employment and skill training, as we explain in the next section. As archaeologists who are working in conflict regions, our experiences show that we can play a greater role in providing this, and, rather than isolating ourselves, we need to consider every angle and possibility for engagement with locals alongside other education and outreach activities. Having pointed out this, our engagement work with Syrian refugees was limited as the archaeology project ended in 2015. Engaging and employing refugees were not feasible given community tensions and the legal status of the refugees. As their status within Turkey becomes more regularized, with access to education and other resources, we hope to be able to offer outreach materials and engagement activities through Batman museum that will serve not only the local Kurdish and ethnically Arab communities but also the refugee community.

\section{Capacity building and training}

One major ethical issue of doing archaeology, particularly in conflict and post-conflict regions, is considering to what extent an archaeology project can support local communities socially, culturally and economically, rather than merely consuming local heritage as a data source. The Ilisu Dam project was one of the largest dam construction projects in the world and generously funded by the DSI in order to finish rescue excavations as quickly as possible. Over 12 years, Başur and Çattepe H.yük excavations employed hundreds of locals. On average the project employed 250 locals every year for six months a year (Figure 6). One of the great benefits of employment for locals was that by ensuring state pensions and insurances were paid, their family members gained the benefit of those same rights, enjoying free health services (under the Turkish state system, healthcare is extended to the entire family of an employed worker). Given that the province of Siirt is one of the least developed regions in Turkey, and people of this region have spent the last 35 years in a conflict context, there have been very few opportunities for employment and to pay into the state insurance and pensions schemes that allow access to things like healthcare.

Compared to the rest of Turkey, the region has much lower levels of educational attainment, related to economic capacity and the weaker support of the state in this region (Yadirgi 2017). As a rescue archaeology and heritage project, our priority was first to employ and support and then to encourage members of local communities to pursue higher education. In order to do this, the project provided employment for young local people prior to taking their university entry examinations

(a requirement for entry into tertiary education in Turkey) during their summer break, allowing them to earn enough money pay university tuition fees and expenses that would otherwise be impossible given the low wages available in the region. The project over the years has employed several students who are from the Siirt and Batman regions but study at universities in other parts of the Turkey. Many of them emhasizsed that without support of the project they could not finish their degrees, as they (or their families) did not have sufficient financial resources.

One of the most critical parts of this success was that some of the students became archaeologists themselves, and have started working in the region professionally. They have attributed their interest in and progression into archaeological careers to exposure to the project as workers, visitors, and students.

The consensus of several of these archaeologists is that their first encounter with archaeology had been with the archaeological rescue project in the region, and particularly that they had been supported economically in the further study by having the project as a source of employment in summer periods. Furthermore, the region's first archaeology museum created great opportunities for local community members. This included employing them, giving training, and skill development opportunities e.g. in conserving artefacts, or archaeological drawing. We found a further benefit in integrating local women from the most conservative social contexts into social and work life through employment as domestic labour. While it may not seem radical, this was in fact a very big 
step to include local women whose social roles generally prevented them from participating in regional life outside of their own homes or those of their immediate relatives. For many women from the smaller villages it was the first experience of paid work. Despite the potential difficulties (for instance, few of the women had access to personal phones, so work had to be arranged through calling male relatives), several female relatives of archaeological workmen from nearby villages were invited to join the project as cooks. Many reported that they very much enjoyed the experience, particularly the opportunity to earn money, and they formed strong bonds with many of the archaeologists from all across Turkey, who could sometimes be found helping them shell beans in the kitchen. This was also, of course, an important opportunity for the archaeologists, particularly those from urban backgrounds, to learn about the local culture.

\section{Training local students}

One of the benefits of involving multiple communities is the added opportunity for training and knowledge exchange. The highly communicative approach of the Ilisu Dam rescue excavation projects,

where we continually transmitted information about archaeological research to local communities, regional government, and national officials, provided a strong foundation for integrating different specialist archaeological practitioners in the project. This open and ongoing dialogue about the archaeology of the site fostered an environment, which allowed the excavation direction to adapt and change to new situations, which included the discovery of a remarkable burial context in 2014; a mass grave containing around 50 individual skeletons.

In 2015 an international team of physical anthropologists led by Hassett began working with the Ilisu project to excavate and identify the bodies in the mass grave. The 2015 excavation season became an opportunity for training a much larger field team in physical anthropological techniques. While the more experienced supervising excavators had worked with human remains previously, for many of the archaeology students, even those who had started graduate-level training, this was the first opportunity to gain hands-on experience in the archaeology of human remains. A group of university students from both local communities and from the large western cities, with levels of experience ranging from none to several years volunteered, joined the physical anthropology team. The complicated stratigraphy of the mass burial required adapting the standard field methodology that we had used on site, while the deteriorating security situation necessitated changes to the excavation and recording plan.

The methods that we subsequently deployed involved a heavy use of technology to mitigate the time pressure, including creating 3D scans using digital photography and drone photography, creating a spatial grid to excavate, and recording the context digitally in two and three dimensions using software like ArcGIS. In order to rescue the burial context, the team had to devise a new form of training

to allow students with limited or no experience of human remains excavation or photogrammetry and '3D' excavation techniques to contribute to the recovery. We had to supplement the very limited Turkish language abilities of the international team with a translator with enough specialist knowledge to convey detailed information. We held a seminar before the beginning of excavation to introduce basic concepts in physical anthropology, allowing students who had no knowledge of the goals of excavating human remains a chance to see how to gather information on past lives from skeletons and teeth to identify sex, age at death, and evidence of disease or trauma. The seminar also introduced the new excavation and recording techniques that students would see in the field, including the spatially located photogrammetric recording, which was new to even the experienced excavators. The open, communicative approach allowed students to understand the decision-making process that led to adopting the photogrammetric recording system, and provided the nonarchaeological photographic and drone teams with an understanding of the excavation's goals. We invited 
the students to 'take over' every aspect of these new techniques, meaning that they were able to learn, practice, and crucially, contribute to the methodology. While it would have been possible, and perhaps easier, to excavate by diktat, without informing the students of the rationale behind the new method of digging, the more reflexive process allowed students better scope to understand (and occasionally challenge) the method.

Physical anthropology forms a very limited part of Turkish archaeological education, with a few notable exceptions where practitioners of high caliber have established departments, for instance in Ankara and Edirne. Therefore this provided a first introduction to the scientific study of human remains for many students. In addition to an introduction in basic skeletal anatomy, the project provided

training in the recording methods used. Students trained in and worked on all aspects of excavation recording, from data entry in spreadsheets to digitization of skeletons from photos to using geographic information systems to the construction of spatially located 3D models of the burials. These final 3D models, visually intuitive interpretations of the work of the excavation team, were presented

to the entire project at the end of the season by the physical anthropologists, and continue to be used to communicate the importance of the excavation at the Ministry of Culture, to international colleagues and collaborators, and at international academic conferences.

This situation created an environment in which all members of the team were able to participate in and experience the physical anthropological research. Students who had little to no knowledge of the study of human remains were able to learn why this is an important aspect of archaeological research, often overcoming longstanding prejudices to do so. Human remains are an emotive subject in any excavation context, and it is important to convey the scientific rationale behind such research. While including findings from the anthropological assessment was appreciated by the regional governor,

future public engagement work funded through a new AHRC grant will focus on highlighting the value of such work to the wider community. In 2018, the physical anthropology laboratory work begun in the field resulted in the publication of a retainer burial on site (Hassett and Sağlamtimur 2018) that made headlines globally, and was extremely well publicized across Turkey. The students who participated in the excavation were able to see their pictures in not only local newspapers, but also on international news sites such as CNN. While the impact of this interest is too recent (July 2018)

to be evaluated immediately, at the very least it has reinforced the importance of the archaeological work at Başur Houyuk to both local and national actors. This level of media interest will also hopefully

cement the interest in archaeological science that was begun during excavation; while the field seasons are in abeyance, students are still able to participate in the physical anthropology research at Ege University.

Exposure to all parts of the research planning process gave the entire excavation team an opportunity to gain training in research planning, methods for excavation of human remains, laboratory analysis methods, data recording and standards, and even the importance of physical anthropological research. The results formed the basis for a successful bid for further funding for outreach activities in the Siirt region (the creation of educational and museum display material, mentioned above), and continued work with the remains at Ege University will provide opportunity for concentrated courses, workshops, and seminars to demonstrate physical anthropological techniques to a wider range of practitioners. The work was also popularized in a book aimed at the general public (Hassett 2016) that has garnered additional interest in physical anthropology.

\section{Dilemma of staying or leaving}

One of the greatest dilemmas for all of us concerned staying or leaving, particularly in 2014 and 2015 when regional and international political tensions escalated dramatically. In 2015 the project had to reconsider its role. The research aim of the last field season in 2015 was to excavate an extremely interesting burial context (the mass grave discussed above), and the project invited a contingent of foreign bioarchaeologists to join the Başur H.yük excavation. Roughly a week after arriving, the Turkish General Election returned the governing party to power and the four-year cease-fire in 
effect with the PKK ended. Siirt is located in a Kurdish region and has seen considerable amounts of PKK activity in the long history of the conflict. It is also the location of strategic Turkish military bases, often targets for the PKK. Likewise, state security forces are extremely active in cracking down on banned activity in the region. Several archaeological projects in the region ceased activity after this, though there were some exceptions. The Siirt projects included the site of both the Çattepe and Başur H.yük excavations; however, the excavation director and cultural ministry officials decided that the more than an hour's drive to the site of Çattepe was too great a security risk to open excavations.

The project did decide to open a limited excavation on the Başur H.yük site, which faced more pressing preservation concerns with the discovery of the mass grave. During the field season, there were several car bombs aimed at military targets; one killed eight conscripted soldiers, another, two (BBC 2015). Soldiers guarding a water facility on the Başur River, which runs behind the

dig complex, were fired upon, and one died. Heavily armed patrols became even more commonplace, and public gatherings were very carefully controlled.

It was at this point that the question of staying or leaving the archaeological work became critical. The director, jointly with the cultural ministry officials, worked to develop strategies to ameliorate both risk to archaeologists and risk to the archaeology. The first concern was for the safety of the archaeologists and workmen. The second concern was the mitigation of harm to the ongoing efforts to integrate the archaeological project into local communities to boost the local economy and to raise awareness and appreciation of regional heritage. While the question of the safety of excavation

participants was necessarily paramount, the key factor in ensuring personal security was in fact the same processes that were integral to coordinating local support for the excavations. This primarily consisted of near-constant dialogue with regional actors, including representatives of local and national government, local communities, the Ministry of Culture, and the workmen and archaeologists themselves. Communication regarding security risks had to be maintained constantly. It was only through dialogue with local communities and national actors that the security situation could be accurately assessed; this was the critical test of our 'communicative approach'.

We cannot simply abandon archaeological practice that seeks to build an inclusive workforce representing diverse life experiences and support for local appreciation for cultural heritage in situations

of political unrest. Many of the students and researchers involved with the Siirt Projects come from the southeastern region and faced considerable hardship in continuing study and work, with or without the excavation. For example, the annual examination of English language skill, required for positions with the Ministry of Culture and itself a common career track for Turkish archaeological graduates, was held during a sustained period of civil unrest in the city of Diyarbakir. Attending required two hours' travel past armed security checkpoints with the possibility of roadside bombings. Those students who did attend the exam were able to hear PKK and government forces exchange fire during the test and were exposed to pepper gas on exit. We, the team members of the rescue project, avoided gathering in public places, like the downtown area of Siirt, and restricted excursions to other heritage sites which we would have normally provided for the students participating in the dig. The deterioration in site security also occasioned adjusting excavation strategy. Aside from leaving work at Çattepe for the season, we shortened the actual period of excavation at Başur H.yük from four months to one. The project framed the research agenda to salvage the partially-exposed mass burial pit, which we considered the most vulnerable part of the site. The excavation of a mass grave is an extremely time-consuming task, requiring a lot of care. The mass burial context at Başur H.yük was in fact extremely comingled remains, which usually would take even longer; however, in order to complete excavation of the 2 by 3 meter pit within one month it was necessary to adopt a salvage strategy. By adopting a mass-capture policy of data collection due to limited field time, and using the remaining time to process the data, it was possible for the project to complete a full four-month season, maintaining the critical links to local communities and the ongoing work of integrating archaeological heritage with local communities. This careful approach led to the 'salvage' of much of the excavated material; the human remains, for instance, were moved to the more secure area of Izmir, and funding from AHRC (Arts and Humanities Research Council UK) we obtained for 
researching them will be used to continue contributing to the education and heritage programmes begun in Siirt Province.

\section{Conclusion}

In this paper, we attempted to present the pitfalls and potentials created by archaeological rescue projects under pressure and in conflict situations. We focus on how we can use the resources for effective public engagement to the benefit of local communities. On one hand, as an archaeologists and heritage specialists, we had two major difficulties: (1) facing the threat of heritage destruction by dam, and therefore attempting to excavate, document, record and digitize archaeologies and heritage of the region in a delimited timeframe, and (2) the more critical dilemma of staying or leaving with the escalation of armed conflict. On other hand, as we have tried to emphasize in this paper, we faced serious difficulties from a professional perspective, questioning our role as an archaeologist and a heritage specialist: are we out there for a data or people? Surely, safety must come first for those working in conflict regions. However, engaging with locals effectively creates tremendous opportunities, and supporting and encouraging the youth in a conflict region through the tools of our profession must be a priority. Particularly, we feel this is ethically paramount in the case of

archaeology in conflict areas.

Of course, the time pressure and security risks of carrying out excavation are precisely the conditions archaeologists must consider when carrying out research in these kinds of rescue contexts. In the case of Çattepe, the security became very fragile and so we had to leave. We did not have any other option. In the case of Başur H.yük there was the impetus of the exposed mass grave, but also the continued goodwill and integration of local communities with the practice of archaeology. The integration of local communities with the practice of archaeology and archaeologists is by far and away more important than digging the site, and this was maintained at Başur through a 'communicative approach'. It is critical to develop mitigation strategies that prioritize local community needs, for instance the need for economic development, opportunities for wage labour, and scholarships

for further study that were needed by local communities in Siirt. The role and position of archaeologists

and heritage specialists should be to encourage the local community to protect their own heritage by direct engagement through offering professional experience and support, and we find that a policy of constant communication and integration of local participants is critical to achieving successful public engagement.

\section{Acknowledgements}

We would like to thank to local community members in Siirt, team members and students of the project, and the Batman

Archaeology Museum. We are grateful to the director of the rescue project, Haluk Saglamtimur, for encouraging and supporting

us to publish this material. We also thank to editors of this journal and anonymous reviewers for their comments

and feedback.

\section{Disclosure statement}

No potential conflict of interest was reported by the authors.

\section{Notes on contributors}

Veysel Apaydin completed his $\mathrm{PhD}$ at the Institute of Archaeology, University College London. His doctoral thesis evaluated uses and abuses of cultural heritage, identity construction and the relationship between heritage, education and 
attitudes towards heritage, taking modern-day Turkey as its case study. He has worked as an archaeologist and heritage

consultant in the United Kingdom and Turkey, and taught in heritage and museum studies and public archaeology

courses at the Institute of Archaeology, University College London. He's recently joined to EC Funded project,

EMOTIVE, as a researcher, at the Department of Archaeology, University of York. He is the author of numerous articles

and edited Shared Knowledge, Shared Power. Engaging Local and Indigenous Heritage (2018). He is also currently editor

of the heritage section of the Open Archaeology Journal.

Brenna Hassett is a bioarchaeologist working on archaeologies of urban health and childhood growth and development.

She has a PhD in Dental Anthropology (Institute of Archaeology, University College London) and her work stretches from

modern anatomical science as a Scientific Associate at the Natural History Museum London to

excavation and bioarchaeological

analysis of remains over many different periods (Neolithic, Early Bronze Age, Post-Medieval) in

Turkey, Egypt,

and the UK. She is rejoining UCL in 2018 with an AHRC funded project to examine the biosocial identities of the human

remains at Başur H.yük, Turkey. She also is very involved with public engagement and outreach activities, authoring a

popular science book about bioarchaeology and urban evolution ('Built on Bones', Bloomsbury) and is a founding

member of the TrowelBlazers collective which seeks to redress gender representation issues in the earth sciences.

\section{References}

Apaydin, Veysel. 2016a. "The Challenge of Neoliberalism and Archaeological Heritage in Turkey:

Protection or

Destruction?" In Archaeology and Neoliberalism, edited by P. Aparicio-Resco, 341-352. Madrid:

JAS Arqueología

Editorial.

Apaydin, Veysel. 2016b. "Effective or not? Success or Failure? Assessing Heritage and

Archaeological Education

Programmes - The Case of .Atalh.yük.” International Journal of Heritage Studies 22 (10): 828-843.

doi:10.1080/

13527258.2016 .1218912$.

Apaydin, Veysel. 2018a. "The Entanglement of the Heritage Paradigm: Values, Meanings and Uses."

International Journal

of Heritage Studies 24 (5): 491-507. doi:10.1080/13527258.2017.1390488.

Apaydin, Veysel. 2018b. Shared Knowledge Shared Power. Engaging Local and Indigenous Heritage. London: Springer.

Apaydin, Veysel. 2018c. "Critical Community Engagement in Heritage Studies." In Encyclopedia of Global Archaeology, Vol

II, edited by Claire Smith, 1-13. New York: Springer.

Ashworth, J. Gregory, and Brian Graham, eds. 2005. Senses of Place: Senses of Time. Aldershot:

Ashgate.

Baird, F. Melissa. 2014. "Heritage, Human Rights, and Social Justice.” Heritage \& Society 7 (2):

139-155. doi: $10.1179 /$

$2159032 X 14 Z .00000000031$.

Baraldi, Sara Bonini, Daniel Shoup, and Luca Zan. 2013. "Understanding Cultural Heritage in

Turkey: Institutional Context

and Organizational Issues.” International Journal of Heritage Studies 19 (7): 28-748. 
BBC. 2015. "Turkish troops killed in bomb attack in Siirt province.” Accessed 26 June 2017.

https://www.bbc.co.uk/news/

world-europe-33985045.

Freire, Paulo. 1993. Pedagogy of Oppressed. London: Routledge.

Graham, Brian, and Peter Howard. 2008. The Ashgate Research Companion to Heritage and Identity.

London: Taylor and

Francis.

Hafsaas-Tsakos, Henriette. 2011. "Ethical Implications of Salvage Archaeology and dam Building:

The Clash between

Archaeologists and Local People in Dar al-Manasir, Sudan." Journal of Social Archaeology 11 (1):

49-76.

Hassett, Brenna. 2016. Built on Bones: 15.000 Years of Urban Life and Dead. London: Bloomsbury. Hassett, Brenna, and Haluk Sağlamtimur. 2018. "Radical 'Royals'? Burial Practices at Başur H.yük and the Emergence of

Early States in Mesopotamia." Antiquity 93 (363): 650-654.

Ireland, Tracy, and Schofield, John. 2015. "The Ethics of Cultural Heritage”. In The Ethics of

Cultural Heritage, edited by

Tracy Ireland and John Schofield, 1-12. London: Springer.

Kitchen, Willey, and M. Ronayne. 2002. "The Ilisu Dam Environmental Impact Assessment Report:

Review and Critique."

Public Archaeology 2 (2): 101-116. doi:10.1179/pua.2002.2.2.101.

Koster, Rhonda, Kristine Baccar, and Harvey Lemelin. 2012. "Moving on From Research ON, to

Research WITH and FOR

Indigenous Communities: A Critical Reflection on Community-Based Participatory Research.”

Canadian Geographer,

56 (2), 195-210.

Logan, William. 2014. "Heritage Rights - Avoidance and Reinforcement." Heritage \& Society 7 (2):

156-169. doi:10.1179/

2159032X14Z.00000000032.

Mark, Pluciennik. 2001. "The Responsibilities of Archaeologists: Archaeology and Ethics.” BAR

S981. Oxford: Archaeopress.

Marshall, Yvonne. 2002. "What is Community Archaeology?" World Archaeology 34 (2): 211-219. doi:10.1080/

0043824022000007062.

McDowell, Sara. 2008. "Heritage, Memory and Identity". In The Ashgate Research Companion to

Heritage and Identity,

edited by B. Graham and P. Howard, 37-54. Aldershot: Ashgate.

Merriman, Nick. 2004. Public Archaeology. London: Routledge.

Meskell, Lynn. 2010. "Human Rights and Heritage Ethics.” Anthropological Quarterly 83 (4): 839859.

Meskell, Lynn, and Peter Pels. 2005. Embedding Ethics. Oxford: Berg.

$14 \mathrm{~V}$. APAYDIN AND B. HASSETT

Meskell, Lynn, and Colette Scheermeyer. 2008. "Heritage as Therapy: Set Pieces From the New

South Africa." Journal of

Material Culture 13 (2): 153-173.

Stephanie Moser, Darren Glazier, James E. Phillips, Lamya Nasser el Nemr, Mohammed Saleh

Mousa, Rascha Nasr Aiesh,

Susan Richardson, Andrew Conner, and Michael Seymour. 2002. “Transforming Archaeology

Through Practice:

Strategies for Collaborative Archaeology and the Community Archaeology Project at Quseir, Egypt.”

World

Archaeology, 34(2), 220-248. doi:10.1080/0043824022000007071.

Moshenska, Gabriel. 2017. Key Concepts in Public Archaeology. London: UCL Press.

Moshenska, Gabriel, and Sarah Dhanjal. 2011. Community Archaeology. Themes, Methods and

Practices. Oxford: Oxbow 
Books.

Rashidirostami, Mahroo. 2018. "Performance Traditions of Kurdistan: Towards a More

Comprehensive Theatre History."

Iranian Studies 51 (2): 269-287. doi:10.1080/00210862.2017.1401861.

Ricouer, Paul. 1999. "Memory and Forgetting.” In Questioning Ethics: Contemporary Debates in

Philosophy, edited by

Richard Kearney and Mark Dooley, 5-11. Oxford: Routledge.

Ronayne, Margaret. 2005. The Cultural and Environmental Impact of Large Dams in Southeast

Turkey. London: Kurdish

Human Rights Project and National University of Ireland, Galway.

Ronayne, Maggie. 2006. "Archaeology against Cultural Destruction: The Case of the Ilisu dam in

Southeast Turkey." Public

Archaeology 5 (4): 223-236.

Ronayne, Maggie. 2008. "Commitment, Objectivity and Accountability to Communities: Priorities for 21st-Century

Archaeology." Conservation and Management of Archaeological Sites 10 (4): 367-381.

Sağlamtimur, Haluk. 2009. "Siirt'in Yemek Kulturunde Perde Pilav ve Buryan.” Metro Gastro 53: 621.

Sağlamtimur, Haluk, and Ali Ozan. 2017. “Mezopotamya'da Nehir Taşımacılı̆̆ı/River Transport in

Mesopotamia." TINA

Denizcilik Arkeoloji Dergisi 8: 26-39.

Schadla-Hall, Tim. 1999. "Editorial: Public Archaeology." European Journal of Archaeology 2 (2): 147-158.

Shoup, Daniel. 2006. “Can Archaeology Build a dam? Sites and Politics in Turkey’s Southeast

Anatolia Project." Journal of

Mediterranean Archaeology 19 (2): 231-258.

Silverman, Helaine. 2011. Contested Cultural Heritage: Religion, Nationalism, Erasure, and

Exclusion in a Global World.

New York: Springer.

Smith, Laurajane. 2006. Uses of Heritage. London: Routledge.

Summerfield, Derek. 2000. “Childhood, War, Refugeedom, and Trauma: Three Core Questions for Mental Health

Professionals." Transcultural Psychiatry 37 (3): 417-433.

Tuna, Numan, Jean Greenhalg, and Jale Velibeyoğlu. 2004. Salvage Project of the Archaeological

Heritage of the Ilisu and

Carchemish dam Reservoirs, Activities in 2001. Ankara: Odtü Taçdam.

Waterton, Emma. 2005. "Whose Sense of Place? Reconciling Archaeological Perspectives with

Community Values:

Cultural Landscapes in England.” International Journal of Heritage Studies 11 (4): 309-325.

doi:10.1080/

13527250500235591.

Waterton, Emma. 2015. "Heritage and Community Engagement." In The Ethics of Cultural Heritage, edited by Tracy Ireland

and John Schofield, 69-88. London: Springer.

Yadirgi, Veli. 2017. The Political Economy of the Kurds of Turkey. From the Ottoman Empire to the Turkish Republic.

Cambridge: Cambridge University Press.

Zimmerman, Larry, D. Karen Vitelli, and Julie Hollowell-Zimmer, eds. 2003. Ethical Issues in Archaeology. Walnut Creek:

Altamira Press. 

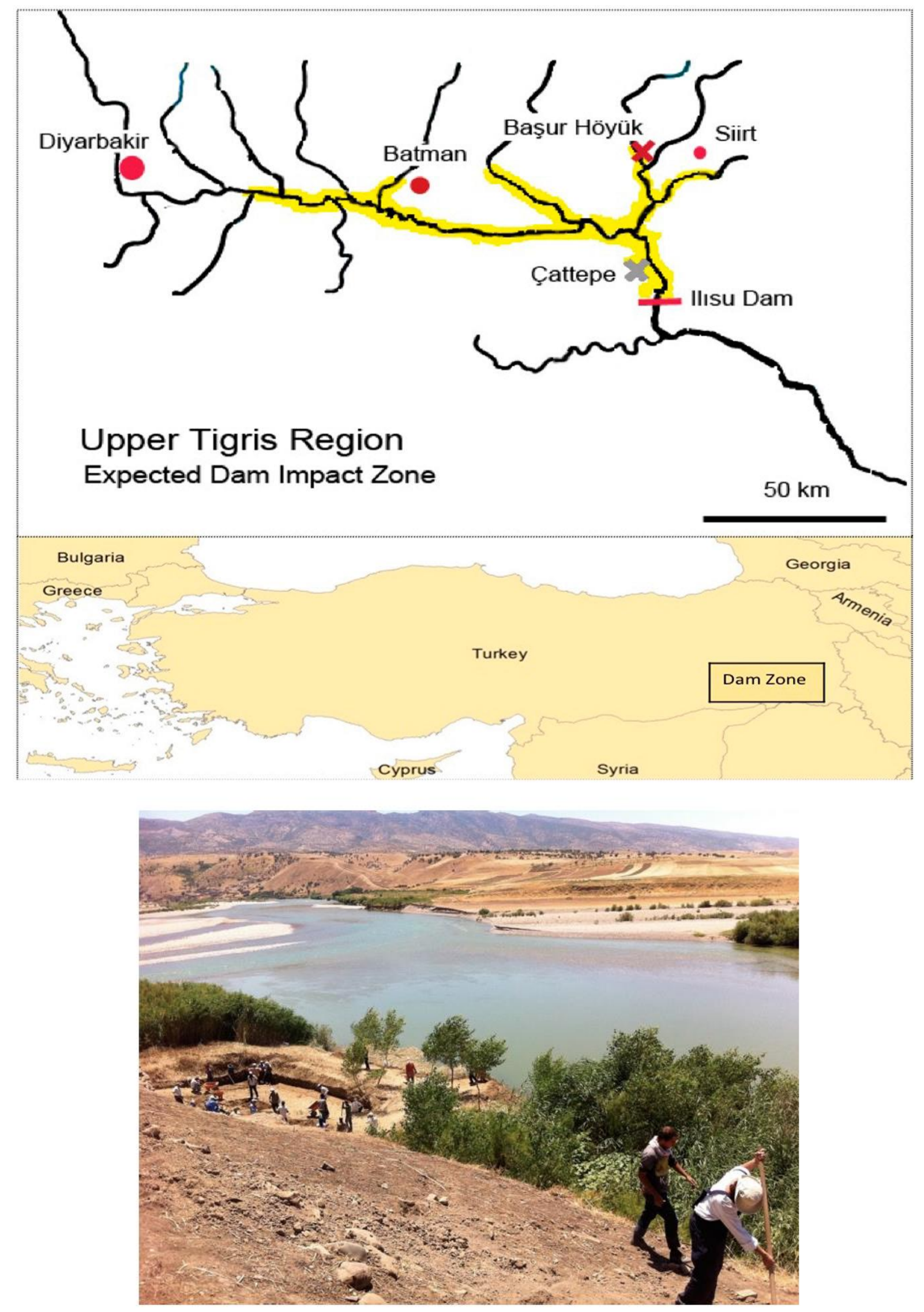

Figure 2. Çattepe höyük, Tigris River and landscape. Source: @Veysel Apaydin. 


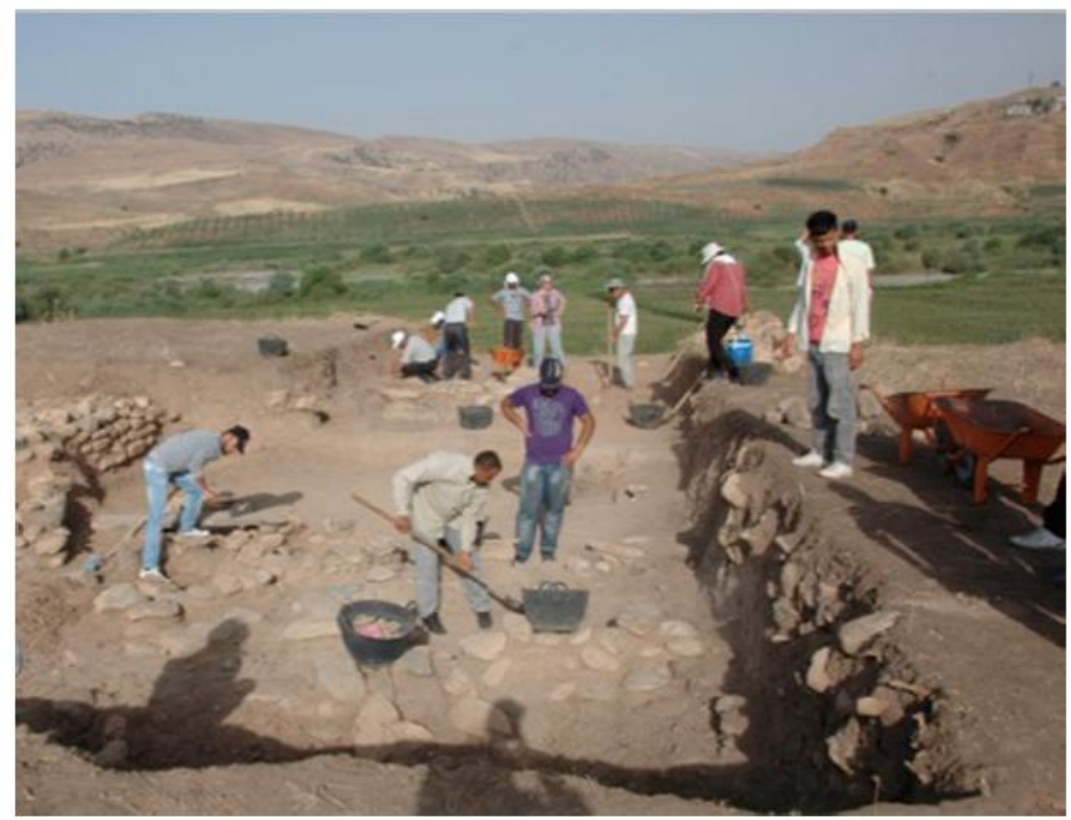

Figure 3. Başur Höyük and overview of the landscape. Source: @Veysel Apaydin.

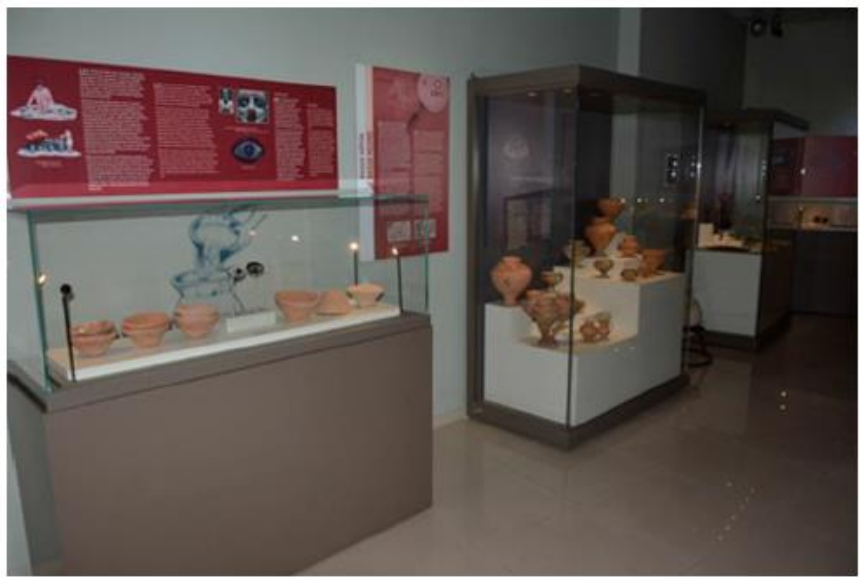

Figure 4. Başur Höyük Exhibition. Batman Archaeology Museum. Source: $\odot$ HalukSaglamtimur. 


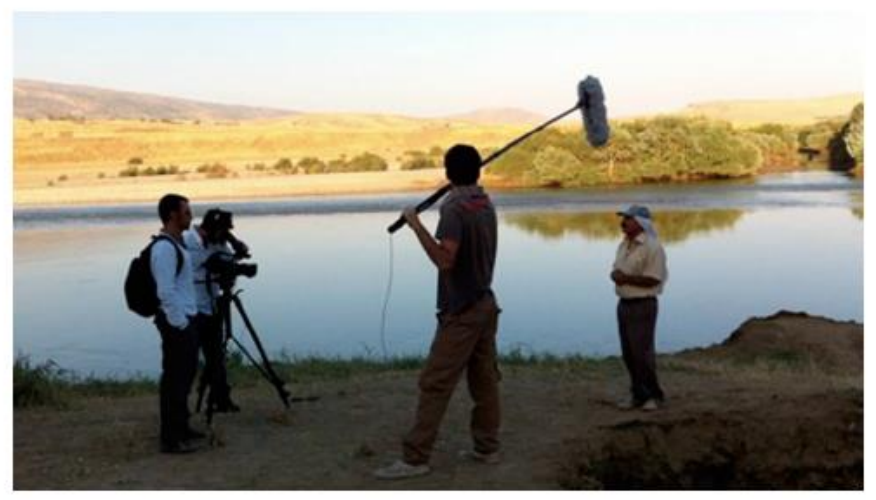

Figure 5. Interviewing local residents about natural and intangible heritage. Source: OVeysel Apaydin.

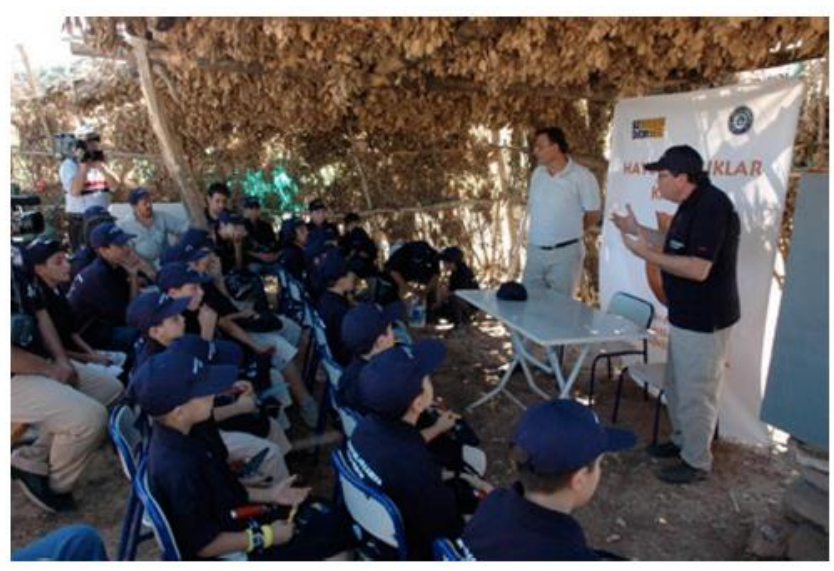

Figure 6. Site lectures for secondary school students at the site. Source: OHalukSaglamtimur. 